\title{
The Difficulties and Countermeasures of ERP Application in Enterprise
}

\section{Financial Management}

\author{
Shuilin Rao ${ }^{1}$ \\ ${ }^{1}$ Guangdong Mechanical \& Electrical Polytechnic,Guangzhou, Guangdong, 510515 \\ 346591653@163.com
}

KEYWORDS: ERP; Enterprise Financial Management; Difficulties and Countermeasures

\begin{abstract}
With the advent of the knowledge economy and the information age, domestic enterprises are facing increasingly serious challenges. In the fierce competition in the market, the integrated operational capabilities of enterprise resource has become an important symbol for the embodiment of market competitiveness of enterprises, the integration of customer needs, internal operations, supplier resources, ERP (Enterprise Resource Planning) system is as more and more enterprises to improve their core competitiveness powerful tool. ERP application is also a high-risk, high investment projects, the whole process of implementation of the existence of various risks. In all ERP implementation projects, scheduled and budget successful implementation of system integration is only $10 \%$ to $20 \%$; no system integration or implementation part of the integrated is $30 \%$ to $40 \%$; and total failure accounted for nearly $50 \%$. Many people that think the implementation of ERP can enhance the image and improve the management of the enterprise, but the result is hardship and passable, even painful lesson. So, how to reduce or eliminate the risk of ERP system implementation is the current problem needed to be solved.
\end{abstract}

\section{Introduction}

With the ERP system is built on information technology, based on a systematic management thinking, and staff for business decision to provide decision management platform running means. ERP systems focus on information technology and advanced management ideas in one, a modern enterprise running mode, reflecting the era of enterprise reasonable allocation of resources to maximize social wealth requirements, a business to survive in the information age, the cornerstone of development. Further, we can manage thinking, three layers of software products, management system is given its definition: (1) Enterprise Management System is a set of system standards by the famous American computer technology consulting and Assessment Group Garter Group Inc. raised its essence is in the MRP II (Manufacturing Resource Planning, Manufacturing Resources Planning) made on the basis of the further development of SCM-oriented ( supply chain management, supply chain management) thought; (2) Is a comprehensive application of the client/server architecture, relational database architecture, object-oriented technology, graphical user interface, a fourth-generation language (4GL), network communications, and other information industry results, to ERP management as of the soul software products; (3) It is the integration of enterprise management concepts, business processes, basic data, human resources, computer hardware and software in the integrated enterprise resource management system. 


\section{The Features and Advantages of Enterprise Financial Management under ERP Environment}

With both in the traditional MRPII or in ERP, financial management has always been the core of the module. Traditional financial management function is mainly based on data analyzed accounting, in order to make the appropriate forecasting, management and control activities, it focuses on financial planning, control, analysis and forecasting, stressing advance planning, a matter of control and after feedback. Due to technical constraints, the traditional financial management through manual operation, artificial scene, two aspects of the inevitable limitations exist: First, the impact of subjective factors. During execution, the quality of individual differences will affect the quality of financial management, especially for key areas of operation, the enterprise will stay hidden. Second, low management efficiency, cost control is high. The ERP financial management module and the previous financial management software is very different, it is closely linked with the whole enterprise production, supply, and it is not only in the interior of each module is fully integrated, and supply chain and manufacturing systems also reached seamless integration of any economic activities of enterprises will be recorded in real time, and reflected in the system, the budget truly beforehand, things in control, after the accurate accounting, occupies a pivotal position in the ERP.

Enterprises must first achieve long-term development, we must in the financial markets at a low cost and effective risk financing, business and management processes and enterprises, directly associated with the interests of shareholders, so that investors can achieve higher than its capital the average return on value.

Traditional financial management is for fund-raising, trafficking and distribution management, object and transfer funds. The implementation of the ERP strategy is the financial management module as the hub of the entire enterprise management system requirements and other modules of enterprise management system have a corresponding interface and the ability to integrate information from each other in the financial center. Therefore, ERP financial management environment is not just for accounting, its object is not only cycling and working capital, including business management, human resources management and other information included in the content management, including accounting supervision, accounting forecasting and decision-making, and according to the principles of information management and information technology, accounting reorganization process, extended to the whole field of business management. In the ERP environment, financial management is not only fully integrated with the respective internal production, business links, and to achieve a seamless connection with all aspects of the supply chain, suppliers, distributors, customers, etc., to achieve the centralized management of corporate resources. ERP system can provide various levels of management required financial statements, regulatory reports and query capabilities, and provides easy-to-use end-user financial management model and analysis module provides various views of external information users, enabling enterprise where the entire supply chain information service users, making enterprise financial information of the business timely and accurate feedback, thereby strengthening the overall management of cash flow and control.

ERP system, financial management module to complete the accounting information to reflect later engaged to the financial management of information processing, and then to a multi-level, integrated, global financial management support. This shift is reflected in: it absorbs and draws on the advanced enterprise financial management practices, improved corporate accounting and financial management business processes that support the operating companies on a global basis for 
the distribution of branches around the world offer a unified accounting and financial management platform, but also to support countries local financial regulations and reporting requirements.

ERP system changes the mode of financial management. Traditional financial management emphasizes reflect accounting data collection and afterwards, it reflects the operating status of the business is lagging behind, only after everything has become a reality in order to take remedial measures to adjust; and ERP systems emphasize advance planning, a matter of control and after feedback, enterprise logistics, capital flow, information flow third-rate one. Where logistics flow, capital flow to the accounting of where the information flow is reflected to go, enabling enterprises to timely response to market conditions. ERP systems improve the business accounting and financial management business processes, support credentials centralized audit, to speed up the month-end closing speed, making financial management more efficient. ERP system to emphasize the collection, analysis and control of business process-oriented financial information, so that after the reorganization of the financial system to support business processes and achieve operational activities cost control.

\section{The Problems of ERP Management}

Financial management foundation is weak. ERP information technology and financial management combined with the product, but the basis of our enterprise financial management is weak currently, many companies basic financial data is not complete, the business process confusion, did not establish a sound regulatory framework, we do not have the basic conditions for running ERP implementation cannot achieve effective ERP applications.

ERP and financial systems design does not match. The current ERP software manufacturer application, ERP systems used by many businesses is based on the establishment of financial management experience, but with the country's financial system does not match. In the ERP selection and Selection, ignoring the link ERP and enterprise financial systems, resulting in post-implementation services can not keep up, resulting in a waste of corporate resources, but increases the workload of staff, can not achieve the effect of running the ERP.

Management ideas and techniques of touch are important. ERP is a technology and management in one system, but the current management exists islands of information, just as information technology ERP, the ERP as a computer simulation tools business hand, not all the information integrated into the system, can not achieve true financial information management. But also in the process of enterprise management, there are different departments and islands of information, resulting in the flow of information: blocked, unable to achieve effective management of ERP.

\section{ERP Application Strategy for Financial Management}

Raise awareness of the extent of the financial information. ERP for the enterprise financial management is of great significance, the use of ERP business processes can be restructured to promote information technology transformation of enterprises. ERP applications in order to achieve financial management, should pay attention to the financial information management to ensure financial security and support of ERP, ERP reinforce learning management, to provide personnel support for the operation and management of ERP systems.

Combined with enterprise financial management system, they select ERP system. ERP product structure and design ideas and enterprise operation mode is closely related to order to do ERP management, we need to select the appropriate enterprise ERP system in accordance with the financial management system. There are currently SAP, Oracle and other well-known foreign ERP 
software, domestic UF, Kingdee, Lima and other software, according to business needs capital, cost, budget, demand accounts and other management needs, combined with business size, management structure and business ERP selection process selection, corporate purchasing, inventory, production, sales, finance and other key management processes analysis, good ERP system design. By exemplary data entry and processes ERP system, the ERP software testing, recommendations for improvement, and constantly improve the ERP system based on actual experience.

Strengthen strategic financial management. In order to do ERP management, we need to consider the long-term, overall planning, according to the enterprise's financial management objectives, planned, systematic drive information management process. The humane management ideas into ERP management, strengthen supervision and control management process, and give full play to their creativity, so as to enhance management efficiency of ERP.

\section{Conclusion}

ERP is not a purely technical project or general-use products, but a systematic project, which requires people to implement, to apply, with the implementation of enterprise need to have the appropriate management foundation and conditions. If in spite of the conditions, what are unified force to ERP, it will inevitably lead to a function of the dummy, the impact of the effect of the implementation of the ERP. Therefore, in the ERP implementation process must be overcome too much emphasis on the adaptability of the enterprise ERP, ERP or superstition advanced, too much emphasis on the adaptability of ERP software these two tendencies, neither conservative and complacent, not superstition, blind worship, must define their needs and the qualifications and capabilities, and improved. Note that, ERP reflect management efficiency requires a process, ERP applications throughout the financial management concept of modern information technology, which will be accompanied by long-term role of the scientific enterprise management. ERP implementation must be based on the characteristics of the actual business area, industry, sector performed, must not engage in blind comparisons. In short, as long as with the implementation of the conditions of enterprises can seize the opportunity to make up the ERP application in the financial management, and in practical work, continue to accumulate lessons learned.

\section{REFERENCE:}

[1] Elizabeth Umble, Ronaldo Haft. Enterprise resource planning: Implementation procedures and critical SUCCESS factors [J]. European Journal of Operational Research, 2003,146: $241 \sim 257$.

[2] Majed A1-Mashari.ERP systems: a research agenda [J]. .Industrial Management and Data Systems, 2002,102 (3): $165 \sim 170$.

[3] Mabert VA, Soni A, Venkataramanan MA. Enterprise resource planning survey of US manufacturing [J]. Production and Inventory Management Journal, 2000,41 (2): 52 58

[4] K.-K.Hong, Y.-G.Kim.The critical success factors for ERP implementation: An organizational fit perspective [J]. Information Management, 2002, 40: $25 \sim 40$.

[5] T. Stein. Making ERP add up-companies that implemented enterprise resource plan-ning systems with little regard to the return on investment are starting to look for quantifiable results [J]. Information Week, 1999,24: 59. 